\title{
Interleukin-1 production in acute viral hepatitis
}

\author{
C MÜLLER, ${ }^{*}$ I GÖDL,$\dagger R$ AHMAD $\ddagger$ H M WOLF,$\ddagger J$ W MANNHALTER, $\ddagger$ AND M M EIBL $\ddagger$ \\ ${ }^{*}$ Department of Gastroenterology and Hepatology II, †Institute of Immunology, University of Vienna, and \\ $\ddagger$ Department of Paediatrics, Wilhelminenspital, Vienna, Austria
}

SUMMARY The in vitro production of interleukin-1 in 15 children with acute hepatitis $A$ and five children with acute hepatitis $B$ was determined by measuring lymphocyte activating factor secreted by peripheral blood monocytes in a thymocyte proliferation assay. Aluminium hydroxide induced production of lymphocyte activating factor was significantly lower in patients with acute hepatitis $A$ as well as patients with hepatitis B as compared with healthy control subjects. In both forms of acute viral hepatitis production of lymphocyte activating factor was severely depressed during the first week, increased gradually during the further course of the illness, but did not reach normal concentrations within the first three weeks after onset of the acute symptoms of the disease. No correlation could be found between in vitro production of lymphocyte activating factor and the severity of liver disease as estimated by the rise of serum concentrations of transaminases, bilirubin, or several parameters of acute phase reaction $\left(\alpha_{1}\right.$ antitrypsin, $\mathrm{C}$ reactive protein, erythrocyte sedimentation rate). The reduced production of interleukin-1, as assessed by determination of lymphocyte activating factor, could explain the only moderate acute phase reaction seen during acute viral hepatitis.

Many inflammatory processes, tissue injuries, microbial invasions, and immunologic reactions induce a generalised host reaction known as acute phase response. It is indicated by several clinical symptoms and laboratory findings, including fever, leucocytosis, depressed serum iron and zinc concentrations, and a dramatic increase in the synthesis of hepatic acute phase proteins. ${ }^{12}$ In recent years much evidence has been accumulated that indicates that a central part is played by interleukin-1, produced primarily by phagocytic cells, ${ }^{3}$ as a mediator of the whole range of acute phase response. Released into the circulation, the pleiotropic nature of this cytokine leads to induction of fever by acting on the hypothalamus, ${ }^{4}$ leucocytosis by increasing bone marrow output, ${ }^{5}$ activation of $\mathrm{T}^{6}$ and $B^{7}$ cells, and an increase in the synthesis of acute phase proteins by the liver. ${ }^{89}$

In contrast with this general picture, it is a well described fact that acute viral hepatitis is characterised by a lack or only a moderate degree of acute phase reaction..$^{10}$ In many patients, especially in children, the disease takes an asymptomatic course, ${ }^{11-13}$ and the development of specific antibodies only indicates viral infection. Even in patients with an icteric course of the disease acute phase symptoms such as fever or myalgia are minimal, ${ }^{11}{ }^{14}$ and laboratory acute phase parameters are only moderately raised. ${ }^{14-16}$

In order to clarify whether a diminished interleukin-1 activity could be responsible for the low or absent acute phase response in acute viral hepatitis we determined the in vitro production of this cytokine by measuring its proliferation-inducing effect (lymphocyte activating factor) on mouse thymocytes.

\section{Patients and methods}

Two groups of children who had been admitted to hospital with acute viral hepatitis were studied: 15 patients (eight boys, seven girls; mean (SD) age: 7.6 (3.8) years, range 2-14 years) had hepatitis $A$ and five patients (three boys, two girls; mean (SD) age: $6.7(2 \cdot 3)$ years, range 4-12 years) suffered from hepatitis $B$ (table 1). The diagnosis was based on characteristic clinical, laboratory, and serological features. The clinical course of acute disease was mild to moderately severe; two children with hepatitis A suffered from a more prolonged disease with raised aspartate aminotransferase and alanine aminotransferase for eight and 10 weeks, respectively. No supportive treatment with substitution of electrolytes and fluid was necessary and no other 
Table 1 Patient characteristics and peak laboratory measurements during acute viral hepatitis. Figures are given as mean (SD)

\begin{tabular}{|c|c|c|c|}
\hline & $\begin{array}{l}\text { Patients with } \\
\text { hepatitis } A \\
(n=15)\end{array}$ & $\begin{array}{l}\text { Patients with } \\
\text { hepatitis } B \\
(n=5)\end{array}$ & $\begin{array}{l}p \\
\text { Value }\end{array}$ \\
\hline Boys & 8 & 3 & \\
\hline Girls & 7 & 2 & \\
\hline Age (years) & $7 \cdot 6(3 \cdot 8)$ & $6 \cdot 7(2 \cdot 3)$ & NS \\
\hline $\begin{array}{l}\alpha_{1} \text { antitrypsin }(\mathrm{g} / \mathrm{l}) \\
\text { (normal: } 0.7-3 \cdot 5)\end{array}$ & $4.3(0.50)$ & $4 \cdot 3(0 \cdot 51)$ & NS \\
\hline $\begin{array}{l}\text { C reactive protein } \\
(\mathrm{mg} / \mathrm{l}) \text { (normal: } \\
<13)\end{array}$ & $23(9 \cdot 0)$ & $<13$ & $<0.025$ \\
\hline $\begin{array}{l}\text { White cell count } \\
\left(\times 10^{9} / 1\right)\end{array}$ & $6 \cdot 8(1.589)$ & $7 \cdot 240(1.415)$ & NS \\
\hline $\begin{array}{l}\left(\times 10^{9} / \mathrm{l}\right) \\
\text { Erythrocyte } \\
\text { sedimentation rate } \\
(\mathrm{mm} \text { in the }\end{array}$ & $3.077(1 \cdot 169)$ & $3.036(.489)$ & NS \\
\hline $\begin{array}{l}\text { first hour) } \\
\alpha_{2} \text { globulin (as } \\
\text { percentage of } \\
\text { total protein)* }\end{array}$ & $8 \cdot 8(2 \cdot 4)$ & $8 \cdot 2(0 \cdot 6)$ & $<0.025$ \\
\hline Bilirubin $(\mu \mathrm{mol} / \mathrm{l})$ & 79 (47) & 111 (77) & NS \\
\hline $\begin{array}{l}\text { Aspartate } \\
\text { aminotransferase } \\
\text { (IU/l) }\end{array}$ & $478(462)$ & 425 (477) & NS \\
\hline $\begin{array}{l}\text { Alanine } \\
\text { aminotransferase } \\
\text { (IU/l) }\end{array}$ & $690(508)$ & $548(500)$ & NS \\
\hline
\end{tabular}

${ }^{*}$ Measured on admission to hospital.

therapeutic measures were taken. After a variable clinical course all the children eventually recovered from hepatitis without complications; none of the cases with hepatitis B took a chronic course.

Twelve healthy young adults served as controls. Previous investigations on a small number of healthy children did not show any difference in production of lymphocyte activating factor by their monocytes as compared with young adults.

Blood for determination of lymphocyte activating factor production was drawn at variable intervals while the children were in hospital. Routine methods were used for determination of white cell counts and differential counts, serum bilirubin concentration, and aspartate aminotransferase and alanine aminotransferase activities; erythrocyte sedimentation rate was measured according to the method of Westergren and the value after the first hour was recorded. These parameters were assessed at least twice a week. C reactive protein and $\alpha_{1}$ antitrypsin serum concentrations, determined by standard nephelometry, were asessed weekly. In addition, serum protein electrophoresis was performed at the beginning of the children's stay in hospital.
PRODUCTION OF LYMPHOCYTE ACTIVATING FACTOR A total of $10 \mathrm{ml}$ of heparinised (preservative free heparin, Immuno) peripheral venous blood was collected and processed within three hours. Mononuclear cells were isolated by buoyant density gradient centrifugation on Lymphoprep (Nyegaard),${ }^{17}$ washed three times with $0.9 \%$ saline and resuspended to $1 \times 10^{6}$ mononuclear cells $/ \mathrm{ml}$ in RPMI 1640 supplemented with $15 \%$ pooled, heat inactivated $\left(30\right.$ minutes at $\left.56^{\circ} \mathrm{C}\right)$ human $\mathrm{AB}$ serum, penicillin $(100 \mathrm{U} / \mathrm{ml})$, streptomycin $(100 \mu \mathrm{g} / \mathrm{ml})$, and L-glutamine $(2 \mathrm{mM})$. Aliquots of $0.5 \mathrm{ml}$ of this cell suspension were poured into wells of a 24 well plate (Falcon) and incubated for 90 minutes at $37^{\circ} \mathrm{C}$ in a humidified atmosphere containing $5 \%$ carbon dioxide. After this, non-adherent cells were aspirated and the plates washed twice with $0.9 \%$ saline. The adherent cell population contained a mean (SD) 87 (7)\% monocytes as judged by morphology and non-specific esterase stain. Then $0.5 \mathrm{ml}$ of aluminium hydroxide $(0.8 \mathrm{mg} / \mathrm{ml})$ dissolved in RPMI 1640 with $5 \%$ pooled human $A B$ serum was added to each well as a stimulant, ${ }^{18}$ and the cells were further incubated for 40 hours. Wells without added aluminium hydroxide were included in each experiment as controls. After incubation the supernatant was harvested, centrifuged at $2500 \mathrm{rpm}$ for five minutes, filtered through a $0.45 \mu \mathrm{m}$ membrane filter (Gellman), and stored at $-20^{\circ} \mathrm{C}$.

ASSAY FOR LYMPHOCYTE ACTIVATING FACTOR ACTIVITY Thymus glands of 4 week old male Balb c mice were removed aseptically, placed in Petri dishes filled with RPMI 1640 medium, teased apart with scissors, and gently pressed through a stainless steel sieve. The single cell suspension obtained was washed three times in RPMI 1640, checked for viability by trypan blue exclusion, and adjusted to $1.5 \times 10^{6}$ viable cells/ml in RPMI 1640 with $5 \%$ fetal calf serum (Flow Laboratories). At the next stage $100 \mu \mathrm{l}$ of this cell suspension and $100 \mu$ l of the supernatant tested (final dilution: 1:10 and 1:20) were added in triplicate with $20 \mu \mathrm{l}$ phytohaemagglutinin (PHA, HA $16,0.2 \mu \mathrm{g} /$ well, Wellcome) into wells of a microtiter plate (Greiner). Cultures were incubated for 72 hours at $37^{\circ} \mathrm{C}$ in a humidified atmosphere containing $5 \%$ carbon dioxide. Sixteen hours before termination of culture each well received $20 \mu \mathrm{l}$ of tritiated thymidine (185 GBq/mmol, Amersham). The radioactivity incorporated into proliferating thymocytes was determined by liquid scintillation in a beta counter (Mark III Searle Analytic Inc). Results of lymphocyte activating factor activity in supernatants were expressed either as counts per minute (cpm) (mean value of triplicate wells in each experiment) or as percent of the mean cpm of 
thymocytes cultured with phytohaemagglutinin and aluminium hydroxide stimulated monocyte supernatants of healthy control individuals.

Data are given as mean (SD) or mean (SEM). The statistical evaluation was performed by Student's $t$ test for unpaired and (when applicable) for paired data.

\section{Results}

SPONTANEOUS PRODUCTION OF LYMPHOCYTE ACTIVATING FACTOR BY CULTURED MACROPHAGES Phytohaemagglutinin comitogenic acitivity on mouse thymocytes, exerted by culture supernatants derived from unstimulated macrophages of children with acute hepatitis A or B and healthy control individuals, is shown in table 2. Neither healthy controls nor patients with acute hepatitis A or B produced substantial amounts of lymphocyte activating factor activity.

\section{ALUMINIUM HYDROXIDE INDUCED PRODUCTION OF} LYMPHOCYTE ACTIVATING FACTOR BY CULTURED MACROPHAGES

As shown in fig 1, phytohaemagglutinin comitogenic lymphocyte activating factor activity in culture supernatants (assayed at a final dilution of 1:10) of aluminium hydroxide stimulated macrophages derived from patients with acute hepatitis A was significantly reduced as compared with the activity found in culture supernatants from healthy controls $(p<0.0005)$. Similarly, culture supernatants of aluminium hydroxide stimulated macrophages from patients suffering from acute hepatitis $B$ also showed a diminished phytohaemagglutinin comitogenic lymphocyte activating factor activity when compared with that of healthy control subjects $(p<0 \cdot 05)$. Phytohaemagglutinin comitogenic lym-

Table 2 Unstimulated production of lymphocyte activating factor by monocytes after incubation for 40 hours. Figures are expressed as mean (SD) counts/minute of tritiated thymidine uptake of mouse thymocytes after cultivation with monocyte culture supernatants for 72 hours

\begin{tabular}{ll}
\hline & $\begin{array}{l}\text { Phytohaemagglutinin } \\
\text { comitogenic } \\
\text { activity }\end{array}$ \\
\hline $\begin{array}{l}\text { Tritiated thymidine incorporation in } \\
\text { mouse thymocytes without culture }\end{array}$ \\
$\begin{array}{l}\text { supernatant }(\mathrm{n}=12) \\
\text { Healthy control subjects }(\mathrm{n}=12)\end{array}$ \\
$\begin{array}{l}\text { Patients with hepatitis A }(\mathrm{n}=15) \\
\text { Patients with hepatitis B }(\mathrm{n}=5)\end{array}$ & $1048(531(203)$ \\
\hline
\end{tabular}

${ }^{*}$ NS.

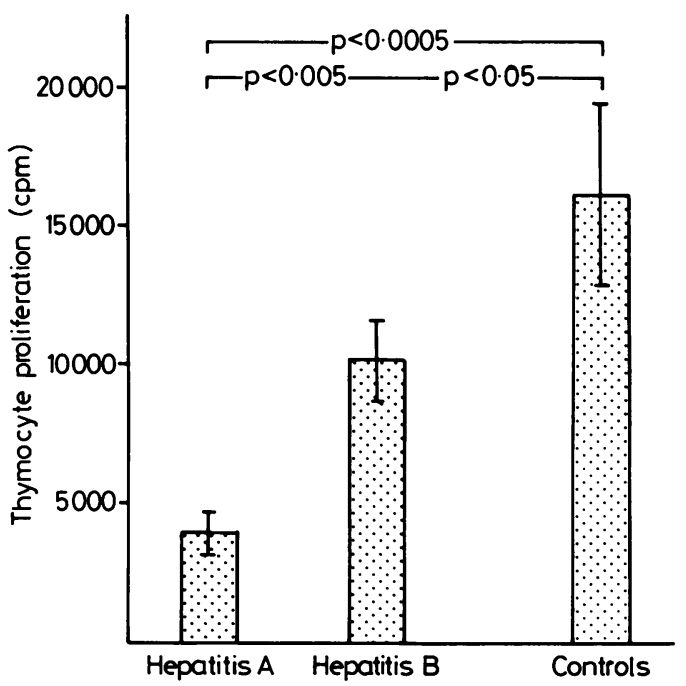

Fig 1 Production of lymphocyte activating factor during acute viral hepatitis. Mean (SEM) of the maximal suppression of production of lymphocyte activating factor of patients during the acute phase of the disease is shown. Supernatants of aluminium hydroxide stimulated cultured monocytes were tested for phytohaemagglutinin comitogenic activity on mouse thymocytes. Tritiated thymidine incorporation (cpm) is given. Hepatitis $A$ $(n=15)$, hepatitis $B(n=5$, nine determinations), control subjects $(n=12)$.

phocyte activating factor activity, derived from cultured aluminium hydroxide stimulated macrophages of patients with hepatitis $A$, was found to be significantly lower than that observed in patients with hepatitis $B(p<0.05)$. The same general pattern of phytohaemagglutinin comitogenic lymphocyte activating factor activity was seen when supernatants were tested at a final dilution of 1:20 (data not shown).

TIME COURSE OF LYMPHOCYTE ACTIVATING FACTOR PRODUCTION DURING ACUTE VIRAL HEPATITIS Production of lymphocyte activating factor during the first week of symtomatic hepatitis A was severely depressed and increased gradually during the further course of the disease (fig 2). In symptomatic acute hepatitis B lymphocyte activating factor production was also diminished during the first week, but was found to be substantially higher than that seen in hepatitis $A(p<0.0005)$. In both forms of acute viral hepatitis, lymphocyte activating factor production increased gradually as time went on but did not reach normal concentrations within the first three weeks after onset of the disease. 

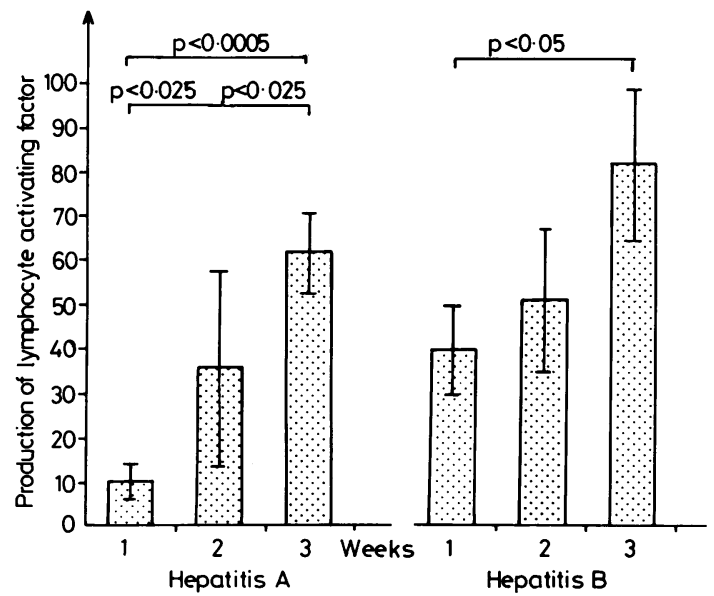

Fig 2 Production of lymphocyte activating factor of aluminium hydroxide stimulated monocytes during the first three weeks after onset of symptoms of acute viral hepatitis and assayed for phytohaemagglutinin comitogenic activity. Lymphocyte activating factor production is expressed as mean (SD) percent of the mean lymphocyte activating factor production (mean cpm in phytohaemagglutinin comitogenic assay) of healthy controls. Hepatitis $A(n=15)$ compared with hepatitis $B$ ( $n=5$, nine determinations): week $1, p<0.0005$; week 2 and 3 , not significant.

CORRELATION OF PRODUCTION OF LYMPHOCYTE ACTIVATING FACTOR WITH ACUTE PHASE REACTANTS AND OTHER LABORATORY PARAMETERS

The absent or only mild changes in acute phase reactants, as documented by their peak values during the course of the disease, are shown in table 1. Serum concentrations of $\alpha_{1}$ antitrypsin, an acute phase reactant known to be moderately raised during acute hepatitis $\mathrm{A}$ and $\mathrm{B},{ }^{15}{ }^{19}$ and of $\mathrm{C}$ reactive protein, found to be increased to a low degree in most cases of acute hepatitis $\mathrm{A},{ }^{14}$ but infrequently in the course of acute hepatitis B, varied independently of lymphocyte activating factor production. Similarly, other parameters of acute phase response were either not raised, such as leucocyte and lymphocyte counts and $\alpha_{2}$ globulin fraction, or only moderately increased (erythrocyte sedimentation rate) (table 1) and did not correlate with lymphocyte activating factor production. In addition, serum concentrations of bilirubin and aspartate aminotransferase and alanine aminotransferase activities varied independently of lymphocyte activating factor production.

\section{Discussion}

We have shown a reduced in vitro production of lymphocyte activating factor of peripheral blood monocytes derived from children with acute viral hepatitis. In particular, lymphocyte activating factor activity, which could be taken as one of the several known biologic activities of interleukin-1, was severely depressed in acute hepatitis $\mathrm{A}$ and to a lesser extent in the small number of patients with hepatitis B investigated, as compared with healthy controls. In both forms of acute viral hepatitis production of lymphocyte activating factor was lowest during the first week of symptomatic illness while impairment was less pronounced during the further course of the disease, but did not reach normal concentrations within the observation period-that is, three weeks after onset of symptoms.

We used the immunoadjuvant aluminium hydroxide as a macrophage stimulant for interleukin-1 production because we have found it to be an inert and reliable interleukin-1 inducer. ${ }^{18}$ Furthermore, in using aluminium hydroxide, we circumvent the abnormal reactivity described for other interleukin1 inducers - that is lipopolysaccharide in the setting of certain hepatic injuries. ${ }^{20}$

The reduced activity of lymphocyte activating factor in supernatants of aluminium hydroxide stimulated peripheral blood monocytes derived from patients with acute hepatitis A or B may be the consequence of a number of different underlying mechanisms, one of them being direct viral infection of the cells involved in lymphocyte activating factor production. Recently, hepatitis B virus also has been shown to infect cells of bone marrow origin, ${ }^{21-23}$ and a decreased production of interleukin- 1 by infected monocytes has been shown as a functional consequence in vitro. ${ }^{24}$ While infection of peripheral blood mononuclear cells is possibly the reason for the diminished interleukin-1 production in hepatitis B, it is less likely to be the cause in hepatitis A. Although hepatitis A virus infection of white blood cells has not been shown yet, one report, however, describes hepatitis A antigen in abdominal lymph nodes, the spleen, and the kidney $^{25}$; this suggests that cells other than hepatocytes may be infected with hepatitis A virus. Infection of macrophages by viruses other than hepatitis has been shown to result in reduced macrophage function; this results in depressed phagocytosis and oxidative metabolism, phagosomelysosome fusion, and killing. ${ }^{26}$ There will also be impaired antigen handling and presentation in HIV infection $^{27} 28$ or a depressed lymphocyte proliferative response to mitogens as a result of a primary alteration of monocyte accessory cell function after infection with influenza $\mathrm{A}$ virus. ${ }^{29}$ Direct viral infection of monocytes, however, is not necessarily accompanied by reduced interleukin-1 production, 
as monocytes infected with influenza $A$ virus in vitro $^{30}$ and monocytes infected with HIV in vivo ${ }^{31}$ showed enhanced production of interleukin-1.

Activity of lymphocyte activating factor in culture supernatants of monocytes may also be reduced because of an increased secretion of prostaglandin $\mathrm{E} 2$, which in turn could inhibit interleukin-1 release. This mechanism seems to be the cause for the reported diminished interleukin-1 activity in monocyte culture supernatants of patients with liver cirrhosis and hepatocellular carcinoma. ${ }^{32}$ In these patients an increased prostaglandin E2 secretion by monocytes was found, and indomethacin treatment of monocytes during culture restored interleukin-1 production. ${ }^{33}$ Even though decreased interleukin-1 production in patients with chronic liver disease was related to the degree of liver cell function ${ }^{34}$ this finding did not hold true for our patients with acute viral hepatitis: we did not observe any correlation with parameters of liver cell necrosis, impaired hepatic clearance, or protein synthesis by the liver.

In addition interleukin-1 inhibitor secretion, which has been described recently, ${ }^{35}$ could also result in diminished interleukin-1 activity in monocyte supernatants. This inhibitor activity has been reported to be present in culture supernatants of monocytes infected with influenza $A$ virus ${ }^{30}$ and shown to be the cause of deficient interleukin-1 production in cytomegalovirus infected monocytes as well. ${ }^{36}$

During the first week of symptomatic disease, children with acute hepatitis A showed a more severe depression of interleukin-1 production by their peripheral blood monocytes than children with acute hepatitis $B$. This finding could either be the result of a true difference in interleukin-1 production between these two forms of acute hepatitis or could mirror a different time kinetic inasmuch as the incubation time until the beginning of the symptomatic phase of the disease is shorter in hepatitis A than in hepatitis $B^{10}$ and the time point of maximal depression of interleukin-1 production could be before the onset of symptomatic disease in hepatitis B. The gradual improvement of interleukin-1 production during the course of acute viral hepatitis points to a mechanism of interleukin-1 depression that is independent of liver cell function. This is illustrated by a slightly protracted course of hepatitis $A$ in two children who nevertheless showed an increase in interleukin-1 production towards normal in the third week after onset of symptoms despite still raised serum aminotransferase activities.

Interleukin-1 has an important helper activity for lymphocyte activation. ${ }^{37-39}$ Reduced interleukin-1 production by peripheral blood mononuclear cells might explain, at least in part, some of the defective immune functions seen during acute viral hepatitis, for example, a reduced lymphocyte transformation in response to phytohaemagglutinin and concanavalin $\mathrm{A}^{40-42}$

In addition to its well known immunoregulatory function interleukin-1 is the principal mediator of the acute phase response in infectious diseases and inflammatory processes, inducing fever, leucocytosis, depressed serum iron and zinc concentrations, and a dramatic increase in the synthesis of hepatic acute phase proteins. ${ }^{2}$ In contrast with most infectious diseases, acute viral hepatitis is characterised by a lack, or only a moderate degree of acute phase reaction, ${ }^{10}$ especially in children. ${ }^{11}{ }^{12}$ This was documented also in our patients as a lack of increase of acute phase reactants in acute hepatitis $B$ and as an only moderate increase in hepatitis $\mathrm{A}^{.16} \mathrm{~A}$ reduced interleukin-1 production by peripheral blood monocytes in acute viral hepatitis, as shown in our study, could well be one of the reasons for the modest acute phase response during the symptomatic phase of the disease. Other explanations for a blunted acute phase response could be a reduction in hepatic interleukin- 1 receptors ${ }^{43}$ during acute viral hepatitis or direct alteration of protein synthesis in infected hepatocytes, which in this way become unable to mount an acute phase response.

In summary, during the acute phase of viral hepatitis in children peripheral blood monocytes show a reduced ability to produce interleukin-1. This finding could explain the well known fact that the acute phase response is only moderate during these diseases.

We thank Immuno AG, Vienna, for the aluminium hydroxide, and Ms L Gschaider for expert technical help.

\section{References}

1 Atkins E. Pathogenesis of fever. Physiol Rev 1960;40:580-646.

2 Dinarello CA. Interleukin-1 and the pathogenesis of the acutephase response. $N$ Engl J Med 1984;311:1413-8.

3 Gery I, Waksman BH. Potentiation of the T-lymphocyte response to mitogens. II. The cellular source of potentiating mediator(s). J Exp Med 1972;136:143-55.

4 Dinarello CA, Wolff SM. Molecular basis of fever in humans. Am J Med 1982;72:799-819.

5 Kampschmidt RF. Leukocytic endogenous mediator/ endogenous pyrogen. In: Powanda MC, Canonico PG, eds. The physiologic and metabolic responses of the host to infection and inflammation. Amsterdam: Elsevier, 1981:55-74.

6 Mizel SB. Interleukin 1 and T cell activation. Immunol Rev 1982;63:51-72.

${ }^{7}$ Falkoff RJM, Muraguchi A, Hong J-X, Butler JL, Dinarello CA, Fauci AS. The effects of interleukin 1 in human $B$ cell activation and proliferation. $J$ Immunol 1983;131:801-5.

8 Dinarello CA. Interleukin-1. Rev Infect Dis 1984;6:51-95.

9 Pepys MB, Baltz ML. Acute phase proteins with special reference to $\mathrm{C}$-reactive protein and related proteins (pentataxins) and serum amyloid A protein. Adv Immunol 1983;34: 141-212. 
${ }^{10}$ Hoofnagle JH. Acute viral hepatitis. Clinical features, laboratory findings and treatment. In: Berk JE, Haubrich WS, Kalsner MH, Roth JLA, Schaffner F, eds. Bockus: Gastroenterology. Philadelphia: WB Saunders, 1985:2856-901.

11 Hadler SC, Webster HM, Erben JJ, Swanson JE, Maynard JE. Hepatitis A in day-care centers: a community-wide assessment. $N$ Engl J Med 1980;302:1222-7.

12 Benenson MW, Takafuji ET, Bancroft WH, Lemon SM, Callahan MC, Leach DA. A military community outbreak of hepatitis type A related to transmission in a child care facility. Am J Epidemiol 1980;112:471-81.

13 Rossi EA. Clinical aspects of acute forms of viral hepatitis. Am J Dis Child 1972;123:277-81.

14 Lemon SM. Type A viral hepatitis. New developments in an old disease. $N$ Engl J Med 1985;313:1059-67.

${ }^{15}$ Moser C, Geiger H, Feist D. Quantitative determination of single serum proteins during acute hepatitis in childhood. Eur $J$ Pediatr 1978;128:123-8.

${ }^{16}$ Kindmark CO, Laurell CB. Sequential changes of plasma protein pattern in inocculation hepatitis. Scand J Clin Lab Invest 1972;29(suppl 124):105-15.

17 Boyum A. Isolation of mononuclear cells and granulocytes from human blood. Scand J Clin Lab Invest 1968;21(suppl 97):77-82.

18 Mannhalter JW, Neychev HO, Zlabinger GJ, Ahmad R, Eibl MM. Modulation of the human immune response by the nontoxic and non-pyrogenic adjuvant aluminium hydroxide: effect on antigen uptake and antigen presentation. Clin Exp Immunol 1985;61:143-51.

19 Van Gool J. Profiles of acute-phase reactants and clinical significance of alpha2-macroglobulin in acute hepatitis B. Inflammation 1983;7:277-89.

20 Lehmann V, Freudenberg MA, Galanos C. Lethal toxicity of lipopolysaccharide and tumor necrosis factor in normal and D-galactosamine-treated mice. J Exp Med 1987;165:657-63.

21 Zeldis JB, Mugishima H, Steinberg HN, Nir E, Gale RP. In vitro hepatitis $B$ virus infection of human bone marrow cells. $J$ Clin Invest 1986;78:411-7.

22 Romet-Lemonne JL, McLane MF, Elfassi E, Haseltine WA, Azocar J, Essex M. Hepatitis B virus infection in cultured human lymphoblastoid cells. Science 1983;221:667-9.

23 Pontisso P, Poon MC, Tiollais P, Brechot C. Detection of hepatitis B virus DNA in mononuclear blood cells. $\mathrm{Br}$ Med $\mathrm{J}$ 1984;288:1563-6.

${ }^{24}$ Knudsen PJ, Strom TB, Zeldis JB. Hepatitis B virus blocks monocyte release of interleukin-1 in vitro. Gastroenterology 1986;90:1738.

25 Mathiesen LR, Drucker J, Lorenz D, Wagner J, Gerety RJ, Purcell RH. Localization of hepatitis $A$ antigen in marmoset organs during infection with hepatitis A virus. $J$ Infect Dis 1978;138:369-77.

26 Pesanti EL, Shanley JD. Murine cytomegalovirus-induced macrophage dysfunction. J Leukocyte Biol 1984;36:133-40.

27 Lane HC, Masur H, Edgar LC, Whalen G, Rook AH, Fauci AS. Abnormalities of $B$ cell activation and immunoregulation in patients with the acquired immunodeficiency syndrome. $N$ Engl J Med 1983;309:453-8.

${ }^{28}$ Mims CA. Interactions of viruses with the immune system. Clin Exp Immunol 1986;66:1-16.
${ }^{29}$ Roberts NJ, Steigbigel RT. Effect of in vitro virus infection on response of human monocytes and lymphocytes to mitogen stimulation. J Immunol 1978;121:1052-8.

30 Roberts NJ, Prill AH, Mann TN. Interleukin 1 and interleukin 1 inhibitor production by human macrophages exposed to influenza virus or respiratory synytial virus: respiratory syncytial virus is a potent inducer of inhibitor activity. J Exp Med 1986;163:511-9.

31 Enk C, Gerstoft J, Moller S, Remvig L. Interleukin 1 activity in the acquired immunodeficiency syndrome. Scand $J$ Immunol 1986;23:491-7.

32 Yokota M, Sakamoto S, Koga S, Ibayashi H. Decreased interleukin 1 activity in culture supernatant of lipopolysaccharide stimulated monocytes from patients with liver cirrhosis and hepatocellular carcinoma. Clin Exp Immunol 1987;67:335-42.

33 Dinarello CA, Marnoy SO, Rosenwasser LJ. Role of arachidonate metabolism in the immunoregulatory function of human leukocytic pyrogen/lymphocyte activating factor interleukin 1 . J Immunol 1983;130:890-5.

${ }^{34}$ Sakamoto $\mathrm{S}$, Koga $\mathrm{S}$, Ibayashi $\mathrm{H}$. Interleukin 1 activity in culture supernatant of lipopolysaccharide-stimulated monocytes from patients with chronic liver disease. Hepatogastroenterology 1984;31:248-54.

35 Liao Z, Grimshaw RS, Rosenstreich DL. Identification of a specific interleukin 1 inhibitor in the urine of febrile patients. J Exp Med 1984;159:126-32.

${ }^{36}$ Rodgers BC. Monocyte-derived inhibitor of interleukin 1 induced by human cytomegalovirus. $J$ Virol 1985;55:527-32.

37 Unanue ER. The regulatory role of macrophages in antigen stimulation between lymphocyte and macrophage. In: Kunkel HG, Dixon JF, eds. Advances in immunology. Vol 31. New York: Academic Press, 1981.

${ }^{38}$ Mizel SB. Physicochemical characterisation of lymphocyte activating factor (LAF). J Immunol 1979;122:2167-71.

39 Rosenwasser LJ, Dinarello CA, Rosenthal AS. Adherent cell function in murine $T$ lymphocyte antigen recognition. Enhancement of murine $T$ cell antigen recognition by human leukocytic pyrogen. J Exp Med 1979;150:709-14.

40 Giustino V, Dudley FJ, Sherlock S. Thymus-dependent lympocyte function in patients with hepatitis associated antigen. Lancet 1972;ii:850-3.

${ }^{41}$ Newble DI, Holmes KT, Wangel AG, Forbes IJ. Immune reactions in acute viral hepatitis. Clin Exp Immunol 1975;20: 17-28.

${ }^{42}$ Chisari FV, Routenberg JA, Edgington TS. Mechanisms responsible for defective human T-lymphocyte sheep erythrocyte rosette function associated with hepatitis $B$ virus infection. J Clin Invest 1976;57:1227-38.

43 Dower SK, Urdal DL. The interleukin-1 receptor. Immunology Today 1987;8:46-51.

Correspondence to Dr C Müller, Department of Gastroenterology and Hepatology II, University Hospital, Garnisongasse 13, A-1090 Vienna, Austria.

Accepted 5 July 1988 